\title{
Efficiency of Rice Husk Ash as Cementitious Material in High-Strength Cement-Admixed Clay
}

\author{
Pornkasem Jongpradist ${ }^{D},{ }^{1}$ Watee Homtragoon, ${ }^{1}$ Raksiri Sukkarak, ${ }^{1}$ Warat Kongkitkul, ${ }^{1}$ \\ and Pitthaya Jamsawang ${ }^{2}$ \\ ${ }^{1}$ Civil Engineering Department, Faculty of Engineering, King Mongkut's University of Technology Thonburi, Bangkok, Thailand \\ ${ }^{2}$ Soil Engineering Research Center, Department of Civil Engineering, King Mongkut's University of Technology North Bangkok, \\ Bangkok, Thailand
}

Correspondence should be addressed to Pornkasem Jongpradist; pornkasem.jon@kmutt.ac.th

Received 30 January 2018; Accepted 24 May 2018; Published 21 June 2018

Academic Editor: Cumaraswamy Vipulanandan

Copyright $(92018$ Pornkasem Jongpradist et al. This is an open access article distributed under the Creative Commons Attribution License, which permits unrestricted use, distribution, and reproduction in any medium, provided the original work is properly cited.

\begin{abstract}
The potential and efficiency of using rice husk ash (RHA) to add up or partially replace Portland cement in deep cement mixing technique are examined. A series of unconfined compression tests on cement-RHA-stabilized clay are conducted to investigate the influence of RHA on the mixture properties. Special attention is paid to its efficiency for increasing the strength by partial cement replacement to obtain high-strength soil cement, and it is compared with fly ash. Test results indicate that up to $35 \%$ of RHA could be advantageously added up to enhance the strength if the cement content in the mixture is larger than $10 \%$. The RHA enhances the strength of cement-admixed clay by larger than $100 \%$ at 28 days. For curing time of 14 and 28 days, the RHA exhibits higher efficiency on Portland cement replacement when the cement and overall cementitious contents are not less than 20 and $35 \%$, respectively. The optimum condition for high-strength mixture is achieved when RHA is added to the $20 \%$ cement content mixture. When compared with fly ash of similar grain size, the efficiency of RHA is higher when the content to be added is greater than $15 \%$. This indicates the suitability of RHA for use in high-strength soil-cement.
\end{abstract}

\section{Introduction}

A large number of researches on utilization of waste materials have been increasingly conducted during the last two decades. For construction industry, the development and use of industrial and agricultural wastes, such as fly ash, blast furnace slag, metakaolin, rice husk ash (RHA), and bagasse ash (BA), are rapidly receiving attention as reviewed in many literatures [1-3]. The use of ashes by the grinding process in cement concrete generally improves the properties of concrete. The concretes containing ground fly ash or RHA are of good quality with reduced porosity and improved resistance to sulphate attack and chloride penetration $[4,5]$ as well as high strength [6-8]. Comparing to the fly ash which is the most common pozzolan being used worldwide in soil stabilization [9], the utilization of rice husk ash as pozzolanic material is still comparatively low.
Rice husk is an agricultural residue which is renewable and available in significant amounts. With the annual rice production of 500 million tonnes in developing countries, approximately 100 million tonnes of rice husk is available annually for utilization in these countries alone. Rice husk is unusually high in ash: close to $20 \%$. The ash content is 92 to $95 \%$ silica, highly porous, and lightweight and has very large external surface area. With the problem of handling and transportation due to its porous structure, a large amount of RHA is, however, treated as waste and disposed at landfill site. Therefore, an increase in utilizations of RHA has enormous potential for waste management as well.

The commercial uses of RHA are in the silica extraction process [10], as pozzolanic material $[4,11,12]$ and other applications. The silica exists in amorphous and crystalline forms depending on the temperature and duration of burning. This amorphous silica is highly reactive, particularly 
when it has a fine particle size. Since Portland cement requires enormous heating in its manufacture, partial replacement of cement by RHA will result in lower energy consumption and may be possible to generate certified emission reductions (carbon credits).

Soil improvement is an alternative way to utilize this ash. A large amount of researches on soil stabilization with cement-lime and RHA have been carried out to evaluate the suitability of these applications [2,13-15]. These indicate the potential of using RHA to partially replace Portland cement in many circumstances. However, all of the abovementioned applications are limited to the shallow stabilization with low cement content. For deep stabilization, research on the potential of using RHA on Portland cement replacement is very limited. This kind of application is usually necessary to the soft ground area from which the paddy is produced and the biomass power plants are located. Thus, the transportation cost of rice husk ash can be reduced, and the feasibility of the application becomes more attractive. For soft clay improvement by deep cement mixing using either mechanical mixing or jet grouting techniques, high cement content is required as the water-to-cement ratio is the strength-controlled parameter [16]. Particularly, when the high strength of the mixture is required such as for slope protection of road or canal embankment $[17,18]$, foundations of road, low-rise building, or small bridge $[19,20]$, or deep excavation support [21, 22], an extremely high cement content must be employed since the strength increase becomes less with increasing cement content at a specific water content. The experimental results from previous studies revealed that a sharp increase in the strength occurred up to the region of $5 \%$ to $25 \%$ cement content. Beyond this range, the effectiveness of increasing cement content becomes inferior [16, 23]. With limitation on efficacy of increasing cement content, recent innovations attempting to enhance the deep cement mixing pile capacity include insertion of a more stiff core into the deep cement mixing pile [24, 25] and enlargement of the pile head [26]. However, expensive additional material and more complicated construction sequence with longer construction time are required.

With the aforementioned issue, the currently practical application of cement content ranges from 100 to $250 \mathrm{~kg} / \mathrm{m}^{3}$ of wet soil for road foundations. However, for foundations of small structures and slope works which require highstrength soil cement, the utilized cement content can be as large as $450 \mathrm{~kg} / \mathrm{m}^{3}$ [27] resulting to a large amount of cement consumption in each project. Thus, in this study, the measurement of potential and efficiency of utilizing RHA on partially replacing Portland cement in deep mixing works is carried out. The efficiency of RHA on Portland cement replacement is discussed with that of fly ash (a widely utilized pozzolanic material of the coal power plants with lower silica content) from the previous study [28].

\section{Laboratory Test}

2.1. Materials. Three kinds of materials including cement, RHA, and soft clay were used in this research. Type I Portland cement with a specific gravity $\left(G_{s}\right)$ of 3.14 is used in
Table 1: Chemical composition of rice husk ash, Portland cement type I.

\begin{tabular}{lccc}
\hline Chemical composition & $\begin{array}{c}\text { Rice husk } \\
\text { ash }\end{array}$ & Cement type I & Fly ash [28] \\
\hline $\mathrm{SiO}_{2}(\%)$ & 93.0 & 20.2 & 42.1 \\
$\mathrm{Al}_{2} \mathrm{O}_{3}(\%)$ & 0.17 & 5.40 & 21.0 \\
$\mathrm{Fe}_{2} \mathrm{O}_{3}(\%)$ & 0.35 & 2.90 & 7.12 \\
$\mathrm{SiO}_{2}+\mathrm{Al}_{2} \mathrm{O}_{3}+\mathrm{Fe}_{2} \mathrm{O}_{3}(\%)$ & 93.5 & 28.5 & 70.2 \\
$\mathrm{SO}_{3}(\%)$ & 0.11 & 2.30 & 0.70 \\
$\mathrm{CaO}(\%)$ & 0.91 & 63.8 & 14.8 \\
$\mathrm{MgO}(\%)$ & 0.42 & 1.50 & 2.00 \\
$\mathrm{Na}(\%)$ & 0.63 & 2.72 & $0-2$ \\
$\mathrm{~K}_{2} \mathrm{O}(\%)$ & 2.82 & 0.30 & $0-5$ \\
$\mathrm{LOI}$ & 4.70 & 2.00 & 7.31 \\
\hline
\end{tabular}

this study. From the previous study [28], the minimum cement content of $10 \%$ is required for partial cement replacement of ground fly ash. For future development, the mixture strength for building foundation is expected to be as high as 1.5 MPa [29]. Therefore, corresponding cementitious material content $\left(C^{*}\right)$ in this study covers the range of 10 to $55 \%$ of dry soil.

The RHA used was a processed waste material incinerated at a controlled temperature $\left(400^{\circ} \mathrm{C}-800^{\circ} \mathrm{C}\right)$ and atmosphere. The chemical composition and physical properties of RHA are given in Table 1. It is black in color. The chemical analysis indicates that the material is principally composed of $\mathrm{SiO}_{2}(93 \%)$ and can be used as a pozzolanic material according to ASTM C 618 [30]. The silica oxide content of RHA is much more than that of fly ash. From previous studies on the use of agrowaste ashes as constituents in concrete, the RHA could be used as a pozzolanic material when it has a fine particle size [31]. Moreover, by grinding, the porous structure of RHA particles would collapse, and the negative effect on water absorption dramatically reduces [32]. Before utilizing in the experiments, the RHA was ground to be finer by the Los Angeles abrasion machine. The gradation of RHA used in this study is controlled to achieve similar grain size distribution of the fly ash used in previous research [28] for comparison. The grain size distribution after grinding is illustrated in Figure 1, together with those of cement and clay used in this study as well as that of the fly ash used for comparison.

The soft clay sampled from King Mongkut's University of Technology Thonburi (KMUTT) located in southern part of Bangkok, Thailand, is utilized in this study. Sampling was performed from the depth of 4 to $5 \mathrm{~m}$ in the soft clay layer. The physical properties of the Bangkok clay are summarized in Table 2. The undrained shear strength, $S_{\mathrm{u}}$, was obtained from unconfined compression (UC) tests ranging from 16 to $17 \mathrm{kPa}$.

2.2. Specimen Preparation. The clay samples utilized in all tests were remolded to water contents of $130 \%, 160 \%$, and $200 \%$. Details on sample preparation are referred to previous works $[23,33,34]$. Only brief description is stated here. 


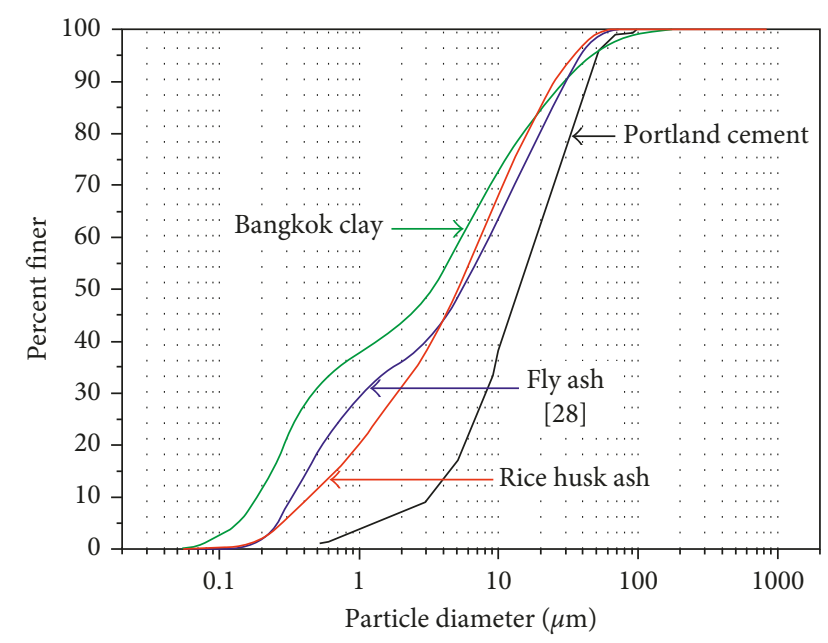

Figure 1: Grain size distribution of rice husk ash, fly ash, Portland cement, and clay in this study.

TABLE 2: Index and physical properties of clay.

\begin{tabular}{lc}
\hline Properties & $\begin{array}{c}\text { Bangkok clay, KMUTT } \\
\text { (this study and }[28])\end{array}$ \\
\hline Water content, w (\%) & 80 \\
Liquid limit, LL (\%) & 119 \\
Plastic limit, PL (\%) & 41 \\
Shrinkage limit, SL (\%) & 14 \\
Liquidity index, LI & 0.5 \\
Specific gravity, GS & 2.68 \\
Total unit weight, $\gamma_{\mathrm{t}}\left(\mathrm{kN} / \mathrm{m}^{3}\right)$ & 14.1 \\
Dry unit weight, $\gamma_{\mathrm{d}}\left(\mathrm{kN} / \mathrm{m}^{3}\right)$ & 7.82 \\
Initial void ratio, $e_{\mathrm{i}}$ & 2.36 \\
Soil classification $(\mathrm{USCS})$ & $\mathrm{CH}$ \\
\hline
\end{tabular}

The amount of water added to a wet clay sample to the desired remolding water content was obtained using the following fundamental equation:

$$
\Delta W_{\mathrm{w}}=\frac{W_{\mathrm{T}}}{1+w_{0}}\left(w_{\mathrm{r}}-w_{0}\right)
$$

where $\Delta W_{\mathrm{w}}$ is the weight of water to be added, $W_{\mathrm{T}}$ is the total weight of the prepared original untreated clay sample, $w_{\mathrm{r}}$ is the required remolding clay water content, and $w_{0}$ is the natural water content of the clay sample.

The remolding clay water content $\left(w_{\mathrm{r}}\right)$ is defined as the water content of the remolded clay prior to the addition of cement slurry. After preparing the remolded clay by fewhour mixing of the disturbed clay and additional water, the cement-rice husk ash slurry having the water-cement ratio (W/C) of 1.0 was mixed with the clay sample. Thus, the overall water content of the paste just at the time of mixing will be the summation of the remolding water and the water in the cement-rice husk ash slurry. The overall water content in the mixture, called the total clay water content $\left(w_{\mathrm{t}}\right)$, is calculated as follows:

$$
w_{\mathrm{t}}=w_{\mathrm{r}}+(\mathrm{W} / \mathrm{C}) C,
$$

where $C$ is the desired cement content (\%) defined as the percentage ratio of the weight of cement to the dry weight of soil.

TABLE 3: The program for cement-admixed clay.

Water content (\%)

Cement content (\%)

Curing time (days)
$130,160,200$

$10,15,20,25,30,35,40,45,55$

$7,14,28$

TABle 4: Summaries of the program for cement-RHA- admixed clay.

\begin{tabular}{lcccc}
\hline Number & $\begin{array}{c}\text { Cement } \\
\text { content (\%) }\end{array}$ & $\begin{array}{c}\text { RHA } \\
\text { content }(\%)\end{array}$ & $\begin{array}{c}\text { Water } \\
\text { content (\%) }\end{array}$ & $\begin{array}{c}\text { Curing time } \\
\text { (days) }\end{array}$ \\
\hline 1 & 10 & $5,15,25,35$ & $130,160,200$ & $7,14,28$ \\
2 & 20 & $5,15,25,35$ & $130,160,200$ & $7,14,28$ \\
3 & 30 & $5,15,25$ & $130,160,200$ & $7,14,28$ \\
\hline
\end{tabular}

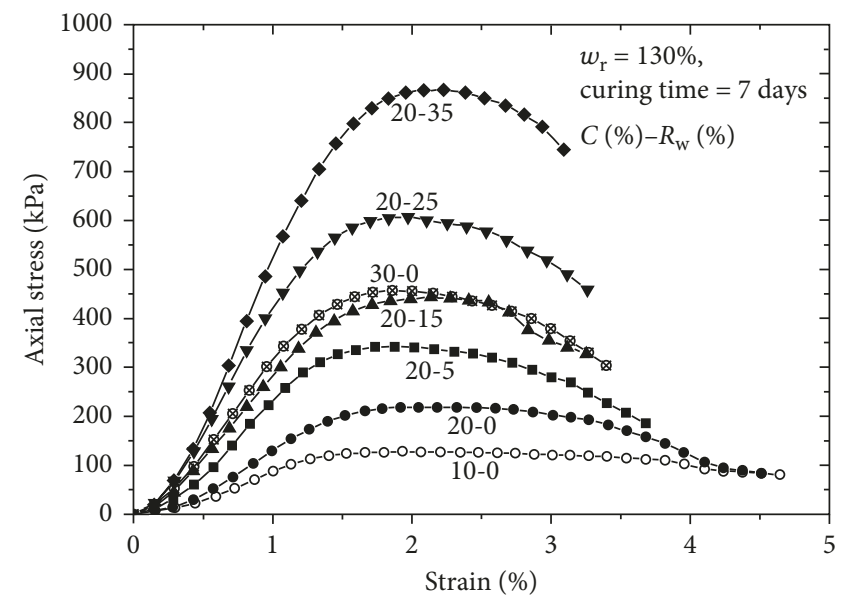

FIGURE 2: Stress-strain curves of treated soil with varying cement and rice husk ash contents at 7 day curing time.

Samples prepared by dropping and pushing the paste into the PVC mold and waxed to prevent moisture loss were cured in the humidity room for a period of 7,14 , and 28 days. After curing, each specimen was removed from the mold and made available for the intended tests. The density of each specimen with the same mixing condition was monitored and kept constant. Finally, for the particular mixing condition, the specimens with smooth surface and with similar densities were selected for testing. After curing, the variation of unit weight of the specimen must be in the range of $\pm 1 \%$.

2.3. Unconfined Compression Tests. Unconfined compression tests were conducted in accordance with ASTM D2166-00 [35]. The specimens have diameter of $35 \mathrm{~mm}$ and height of $70 \mathrm{~mm}$. The rate of shearing was maintained at $1.14 \%$ per minute, and the test program for cement-stabilized clay without and with RHA is summarized in Tables 3 and 4, respectively, with 3 specimens per mixing.

\section{Results and Discussion}

3.1. Unconfined Compressive Strength. Figure 2 illustrates the stress-strain relationships from unconfined compression tests of samples cured at 7 days with remolding water 


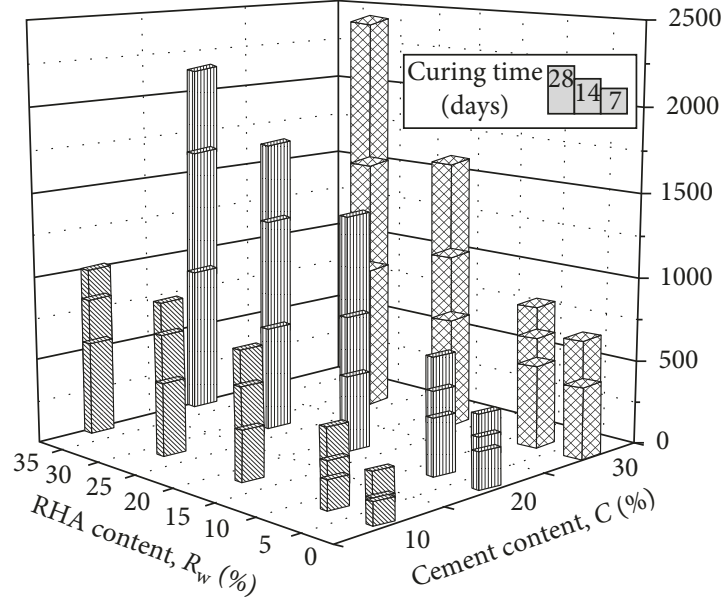

(a)

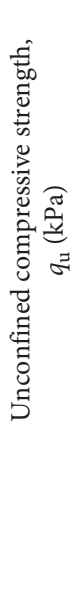

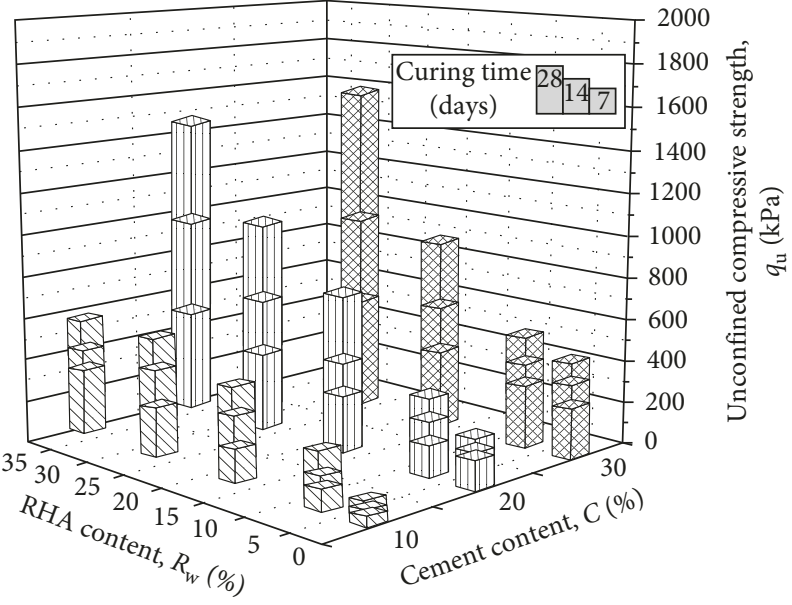

(b)

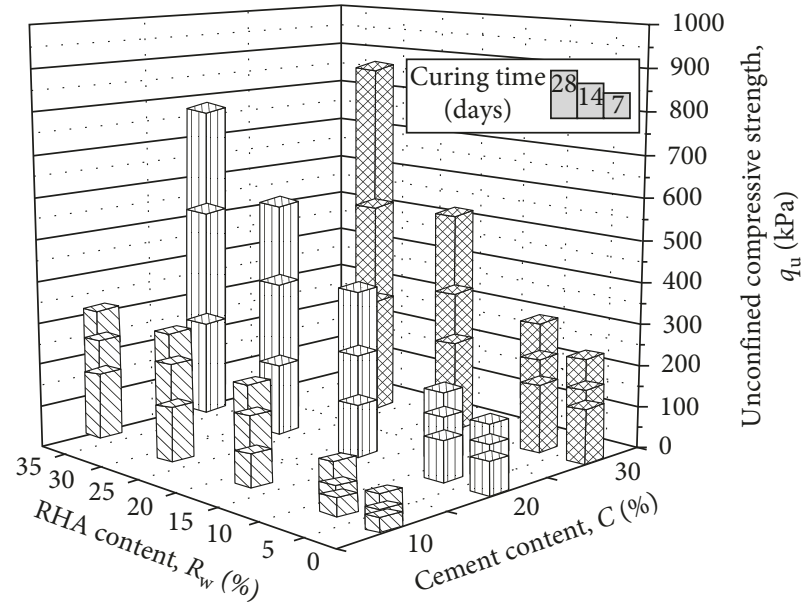

(c)

FIGURE 3: Relationships between unconfined compressive strength against cement and rice husk ash contents for different remolding water contents and curing time. $w_{\mathrm{r}}=130 \%$ (a); $160 \%$ (b); $200 \%$ (c).

content of $130 \%$. The results from samples with cement contents of 10,20 , and $30 \%$ without RHA and those of $20 \%$ cement content with varying RHA content are compared. The maximum stress, or strength, of material increases with increasing RHA content. This demonstrates that addition of RHA can significantly enhance the strength of the mixture with only 7 days of curing. A series of scanning electron microscopy (SEM) have been conducted. The strength increase can be explained by the interaction of microstructural mechanisms. Together with explanation by Chew et al. [36], the mechanisms include hydration and pozzolanic reactions, surface deposition, and shallow infilling by cementitious products on clay clusters, as well as the presence of water trapped within clay clusters. By adding 15\% RHA in the mixture having a cement content of $20 \%$, the same strength to mixture with a cement content of $30 \%$ can be obtained. The influence of RHA content on unconfined compressive strength of cement-RHA-treated clay for different water contents and curing time is summarized in Figure 3. Depending on the addition rate and mixing components, RHA enhances the unconfined compressive strength of cement-admixed clay by up to larger than $100 \%$ at 28 days. This indicates the preliminary possibility of using RHA for replacing cement or adding up in cement deep mixing works.

Besides the cement content and RHA content, other influencing parameters on the strength characteristics of mixtures are water content and curing time. The water is essential in hydration process to improve strength characteristics. However, excessive water from hydration process leaded to drop of strength due to the increase in distance between interparticle or intercluster of particle spacing [37]. Figure 3 shows that the strength of mixtures with a remolding water content of $130 \%$ is 2 times larger than that with a remolding water content of $200 \%$ having the same amount of cement content, RHA content, and curing time. The influence of curing time on strength development can also be observed in Figure 4. For all the selected cases, the strengths increase with time but the rate of increase becomes smaller. The strength at the curing time of 28 days can be larger than 2 times of that at the curing time of 7 days. From overall testing results, it can be concluded that the strength characteristics of cement and cement-RHA-stabilized 


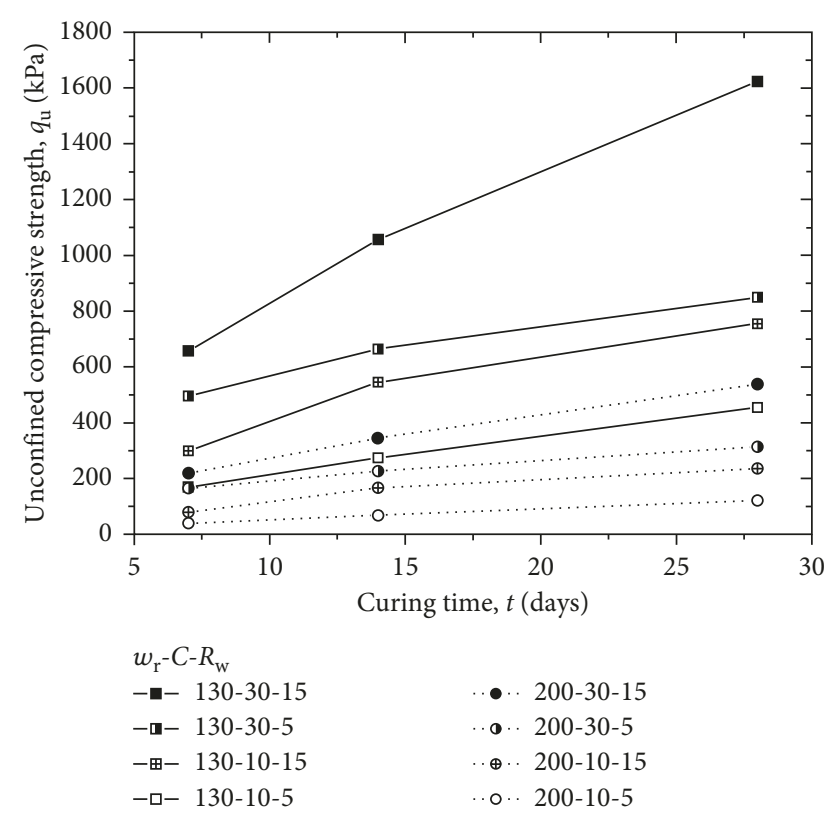

FIGURE 4: Relationship between unconfined compressive strength and curing time of RHA-cement-treated clay.

clay depend on mixing ratios (cement content, RHA content, and remolding water content) and curing time.

3.2. Modulus of Elasticity. According to the current application as bearing resistance and design method of cement column which uses $50 \%$ of strength, the modulus of elasticity in terms of secant $\left(50 \% q_{\mathrm{u}}\right)$ modulus $E_{50}$ was selected to be investigated in this study. Figure 5 depicts the relationships of elastic modulus and strength of the cement with and without RHA admixed at the curing time of 7 and 28 days. $E_{50}$ of cement-RHA-stabilized clay at the curing time of 7 and 28 days can be estimated as $76.5 q_{\mathrm{u}}$ and $84 q_{\mathrm{u}}$, respectively. Meanwhile, for cement-stabilized clay, the relationships can be approximated as $78 q_{\mathrm{u}}$ and $73 q_{\mathrm{u}}$ for the curing time of 7 and 28 days, respectively. The observed moduli of elasticity of cement-RHA-stabilized clay at a curing time of 7 days are almost the same with those admixed with cement at the same strength. However, for a curing time of 28 days, $E_{50}$ of cement-RHA-stabilized clay are higher. This is probably due to the additional effects from RHA. This indicated that by adding with RHA, not only the strength could be gained, the deformation characteristic was also improved. However, when compared with the moduli of elasticity of cement-fly ash-stabilized clay at the same strength from previous study, the values of cement-RHAstabilized clay are lower for both 7 and 28 days of curing time. Furthermore, unlike the cement and cement-fly ashstabilized clays [28] and concrete [38], the ratios of $E_{50}$ and strength of the cement-RHA-stabilized clays at 7-day curing time were smaller than the ones at 28-day curing time.

\section{Efficiency of RHA as Cementitious Material}

4.1. Efficiency of RHA on Strength Increase. In this part, the efficiency of rice husk ash as an additional Portland cement

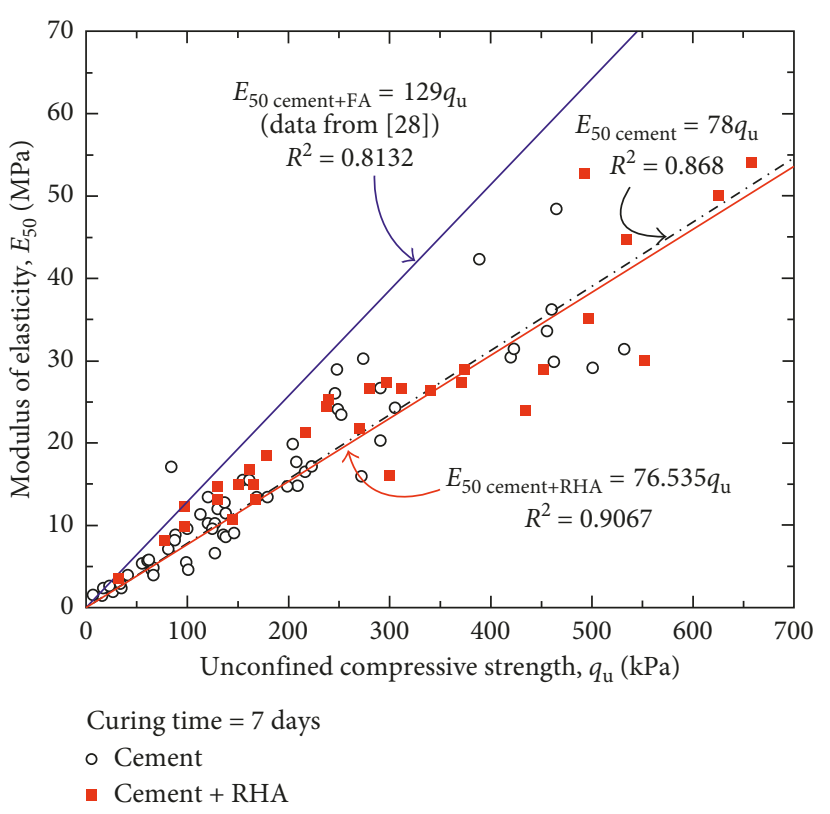

(a)

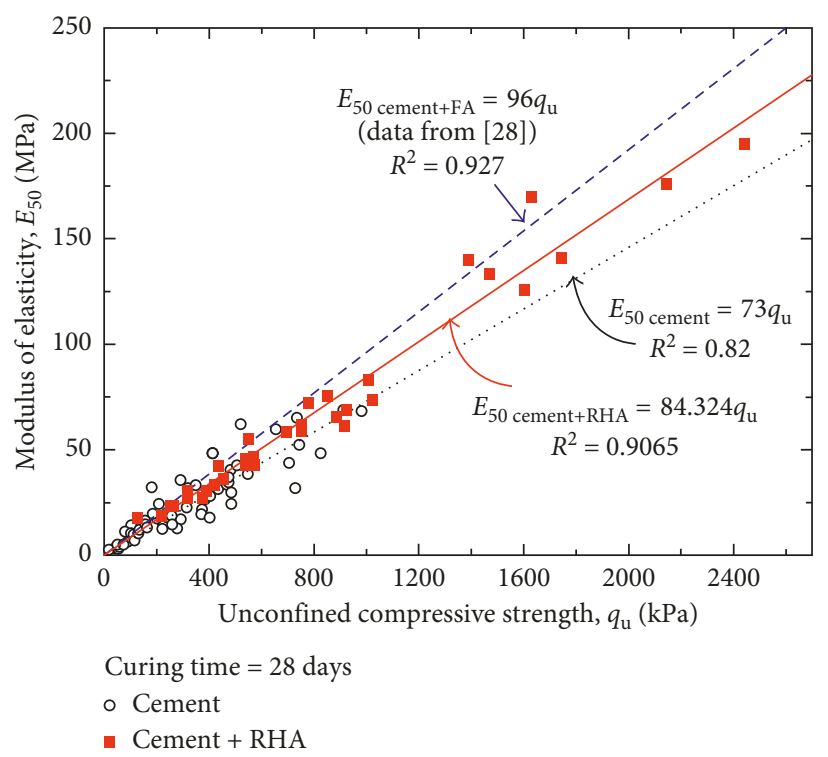

(b)

FIGURE 5: Modulus of elasticity- $\left(E_{50^{-}}\right)$unconfined compressive strength relationships of cement and cement-rice husk ashadmixed clay. Curing time: (a) 7 days; (b) 28 days.

is discussed. Figures 6(a)-6(c) illustrate the strength changes of the cement-admixed clay and the cement-admixed clay with added RHA of various cement contents $(10,20$, and $30 \%$ ) for different curing times. In each figure, the results for different water contents are shown. The cementitious content $\left(C^{*}\right)$ is defined as the summation of the cement $(C)$ and RHA contents $\left(R_{\mathrm{w}}\right)$. It can be observed that when compared to the strengths of the cement-admixed clay with the same cementitious content, the additional RHA leads to the decrease of strength of the mixtures with RHA having a cement content of $10 \%$ for all remolding water contents at the curing time of 7 days. This is probably because the pozzolanic 


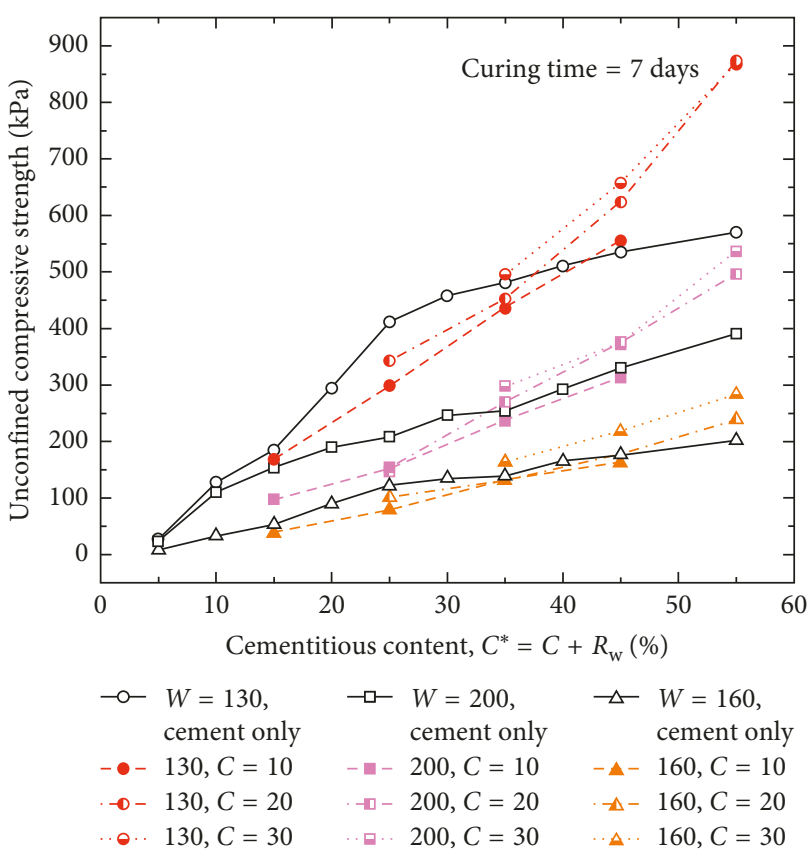

(a)

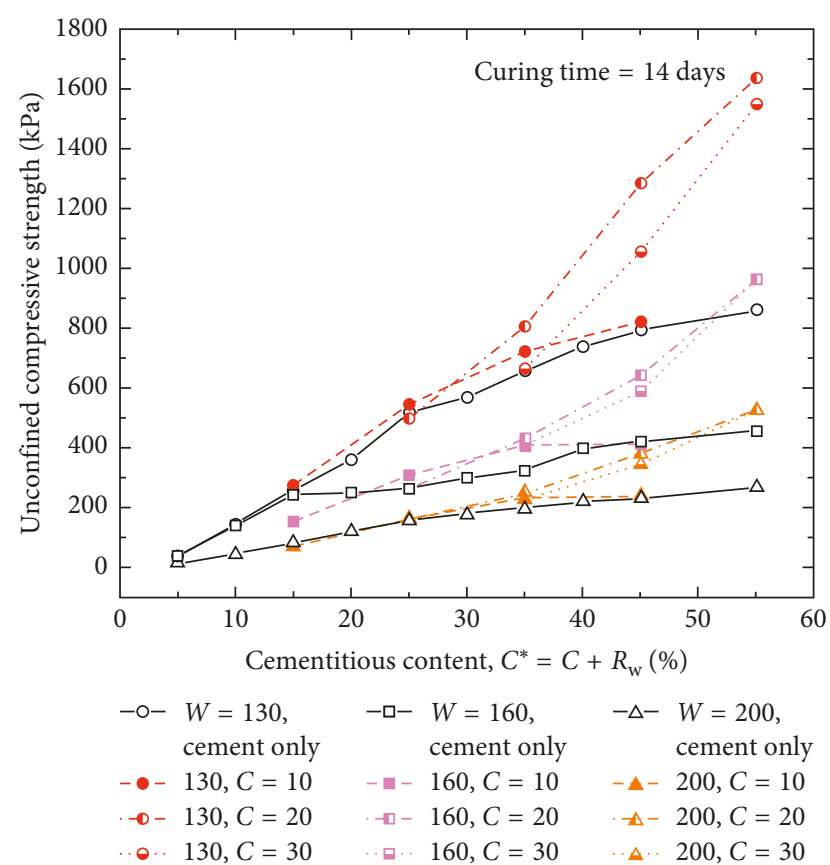

(b)

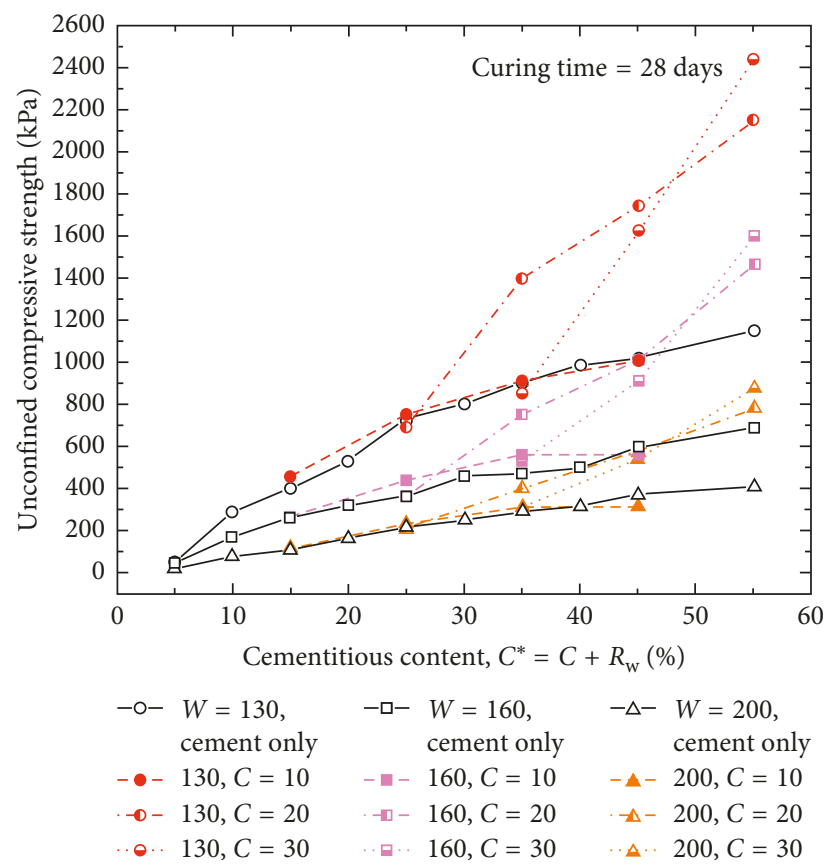

(c)

FIGURE 6: Relationships between unconfined compressive strength and cementitious material contents for different remolding water contents and curing time. Curing time: (a) 7 days; (b) 14 days; (c) 28 days.

reaction has not fully taken place due to the insufficient amount of product from the hydration process. For the mixtures with all remolding water content at the curing time of 14 and 28 days, the strengths of the RHA-added mixtures are approximately the same as those of the cement-admixed clay without RHA having the same cementitious content.

For the 20\% cement content mixtures with RHA, the strengths of the mixture are moderately smaller or almost equal to those of the mixture without RHA for a small amount of RHA addition. With increasing RHA content to not less than $15 \%$, the strengths become larger than those of the mixture without RHA and significantly larger when the additional RHA content is equal or greater than $25 \%$. These behaviors are observed for the mixtures at all curing times. The strength increase continues with the addition of RHA content up to $35 \%$, which is $64 \%$ of overall cementitious content for this condition. 


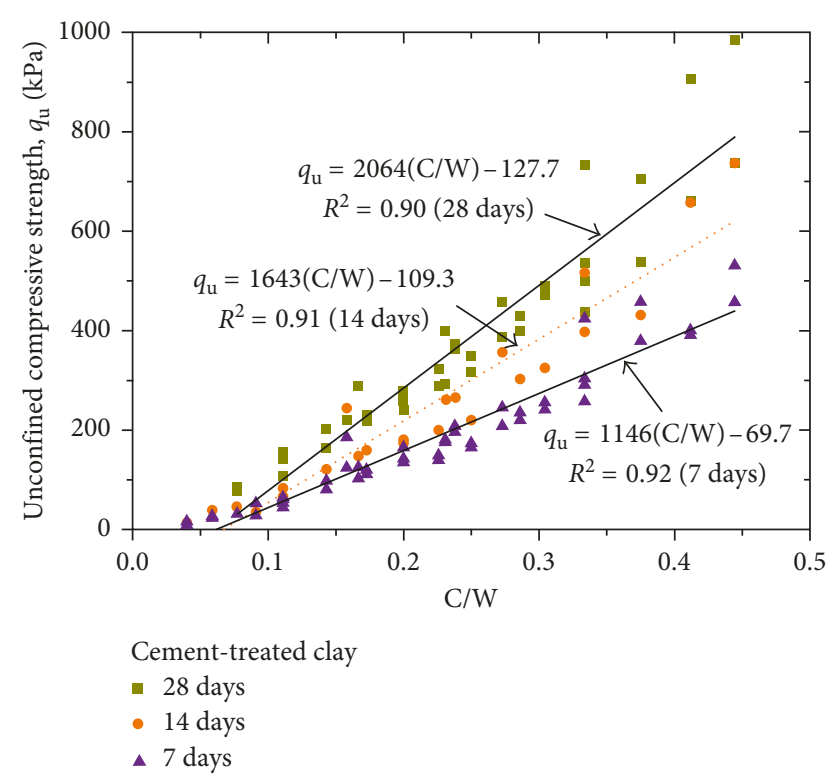

Figure 7: Unconfined compressive strength versus $\mathrm{C} / \mathrm{W}$ ratio at 7,14 , and 28 days of curing time.

TABLE 5: The values of $(K)$ and $(a)$ at various curing times.

\begin{tabular}{lcc}
\hline Age (days) & $K$ & $a$ \\
\hline 7 & 1146 & 69.7 \\
28 & 2064 & 127.7 \\
\hline
\end{tabular}

For the mixtures with RHA having 30\% cement content at all curing times, the strengths of the RHA-added mixtures having the same cementitious material content become greater than those of mixtures without RHA when only 5\% RHA content is used. Comparing with previous results of the $20 \%$ cement content mixtures with RHA, it seems that the strengths of the mixtures with RHA are larger than those of mixtures without RHA if the cementitious material content is not less than 35\%. The rapid increases of strength can be clearly seen when the additional RHA content is equal or greater than $10 \%$. Moreover, for the mixtures with RHA having cement contents of $20 \%$ and $30 \%$, the strengths of mixtures with the same cementitious material content $\left(C^{*}\right)$ are approximately the same when $C^{*}$ is $45 \%$ and $55 \%$. Since the cost of RHA is inexpensive, this suggests that the cement content of $20 \%$ is optimum for cement RHA-admixed clay for the range of cementitious content in this study.

4.2. Considering as Equivalent Cement Content and Comparison with Fly Ash. The amount of RHA content to be added is converted to additional cement amount from cement base, the so-called equivalent cement content $C^{\prime}$, by means of back calculation of unconfined compressive strength. Widely used empirical Féret's equation modified by [39] for concrete strength analysis is adopted:

$$
q_{\mathrm{u}}=K\left[\frac{C+k P}{W}-a\right]
$$

where $k$ denotes the efficiency factor of any pozzolanic materials for replacement or adding up which is the function of chemical composition and grain size distribution of the pozzolanic materials and $C, W$, and $P$ are the cement, water, and pozzolanic contents (\%), respectively. By replacing the term $k P$ with $C^{\prime}$, the parameter $C^{\prime}$ can be calculated as

$$
C^{\prime}=\left[\frac{q_{\mathrm{u}}}{K}+a\right] W-C
$$

Prior to the calculation of $C^{\prime}$, the other parameters in (4), that is, $K$ and $a$ must be determined. This can be done by considering the mixtures without RHA. The relationship between unconfined compressive strength and cementwater ratio $(\mathrm{C} / \mathrm{W})$ is illustrated in Figure 7.

In this study, $W$ is the total water content subtracted by a constant. From the analysis, this constant is found to be 80 which is close to the natural water content of the tested clay. However, further investigations on how this constant changes for clays with other natural water contents should be examined. The $K$ values for the curing time of 7, 14, and 28 days were then calculated from slopes of the lines. The parameter $a$ in the Papadakis and Tsimas equation for the curing time of 7,14 , and 28 days was obtained from $y$ interception of each line as well. The calculated values are summarized in Table 5.

Substitutions of the unconfined compressive strength of cement-rice husk ash-treated clay, the mixing proportion and the parameters in Table 5 for each curing times, and the $C^{\prime}$ values are obtained. Figures 8 and 9 show the relationship between the actual content in the mixture and the calculated equivalent cement content $C^{\prime}$ of cementRHA-treated clays for various remolding water contents and curing times (only the curing time of 7 and 28 days are illustrated) together with those of cement-fly ash-treated clays from previous study and the straight line with slope $1: 1$. From the figures, it is seen that the efficiency of cement replacement of rice husk ash increases with increasing curing time and cement content and decreasing water content. For a curing time of 7 days, adding RHA improves the strength of the mixture with lower equivalent efficiency as most graphs are under 1:1 line. However, for higher cement content and lower water content (e.g., $C=30 \%$ and $w_{\mathrm{r}}=130 \%$ ), the graph is above $1: 1$ lines. For a curing time of 28 days and cement content of not less than $20 \%$, adding RHA enhances the strength of the mixture with higher efficiency compared to Portland cement as the data are above the $1: 1$ line. The high efficiency of adding RHA can continue to be $35 \%$ for the cement contents of 20 and $30 \%$, which means that the ratios of RHA to cement are greater than one. The finding in concrete work that the RHA can be effectively used up to $50 \%$ replacement of Portland cement $[38,40]$ indicates that the efficiency of RHA on cement replacement in cement-stabilized clay is superior to that in concrete. For mixtures with a cement content of $10 \%$, adding RHA exhibits equal efficiency to cement up to adding content of $15 \%$. With further increasing RHA content, the efficiency decreases. 


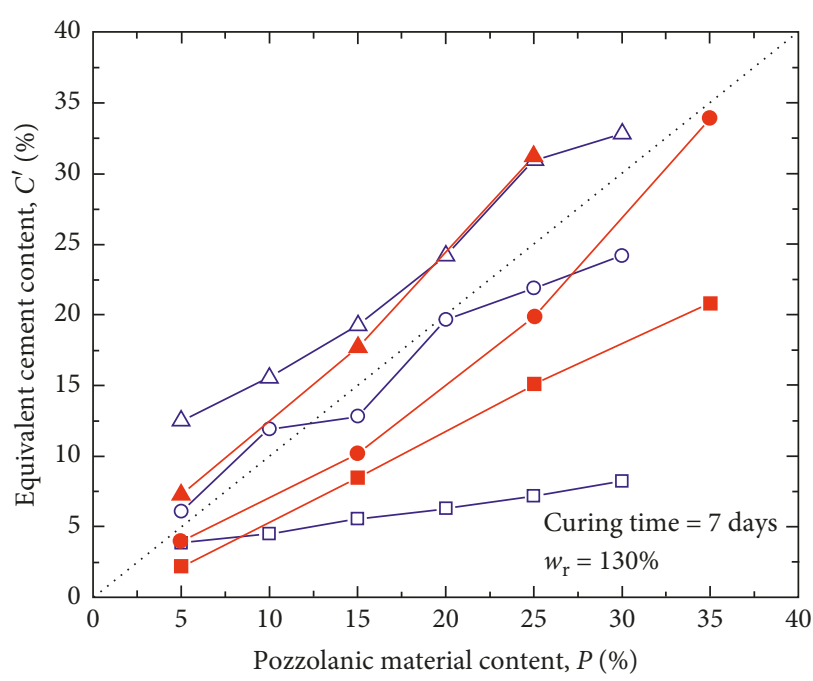

$\begin{array}{ll}\text { Fly ash (data from [28]) } & \text { Rice husk ash (this study) } \\ -\square-C=10 \% & --C=10 \% \\ -\bigcirc-C=20 \% & -\bullet-C=20 \% \\ -\triangle-C=30 \% & -\Delta-C=35 \%\end{array}$

(a)

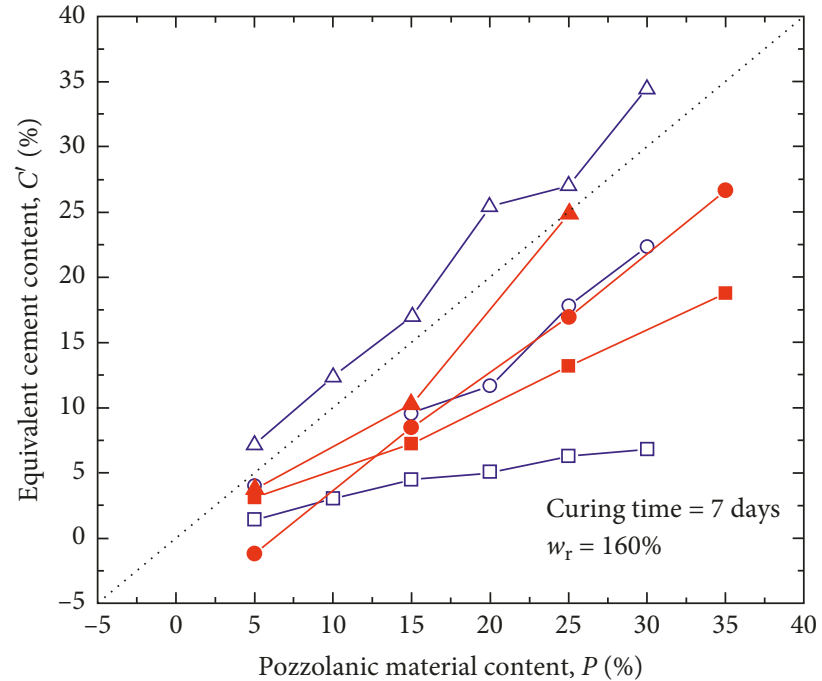

Fly ash (data from [28])

- $\square-C=10 \%$

-०- $C=20 \%$

$-\triangle-C=30 \%$

$$
\begin{aligned}
& \text { Rice husk ash (this study) } \\
& -\square-C=10 \% \\
& -\bullet-C=20 \% \\
& -\boldsymbol{-}-C=35 \%
\end{aligned}
$$

(b)

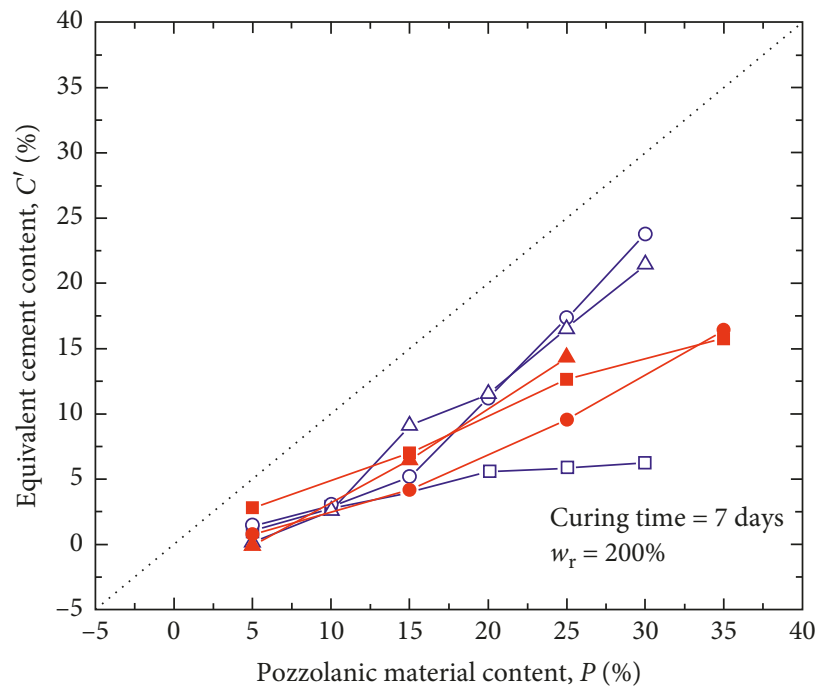

Fly ash (data from [28])

Rice husk ash (this study)

- $\square-C=10 \%$

-O- $C=20 \%$

$-\triangle-C=30 \%$

- $\mathrm{c}=10 \%$

$-\boldsymbol{\Lambda}-\mathrm{C}=35 \%$

(c)

Figure 8: Relationships between calculated $C^{\prime}$ and actual pozzolanic content (RHA and fly ash) added in cement-treated soil at 7 days of curing time. $w_{\mathrm{r}}=130 \%(\mathrm{a}) ; 160 \%$ (b); $200 \%$ (c).

Next, the comparison between the efficiency of replacement of fly ash and RHA is made and discussed. At the early age ( 7 days), the efficiency on Portland cement replacement of fly ash is superior to that of RHA. This can probably be explained that, at the initial time, the structure from products of pozzolanic reactions is still not playing an important role. Thus, the increase in strength would come from filling of ash into clay clusters. Since fly ash has spherical shape, it is easier than RHA to fill in. Moreover, since the fly ash has $\mathrm{CaO}$, there might be the additional hydration effect from the fly ash. For long term, it can be distinguished at the adding content of $15 \%$. For pozzolanic content less than or equal to $15 \%$, the fly ash exhibits better efficiency, whereas the RHA is superior when the content to be added is greater than $15 \%$. This suggests that the RHA is more suitable for making high-strength soil-cement. 

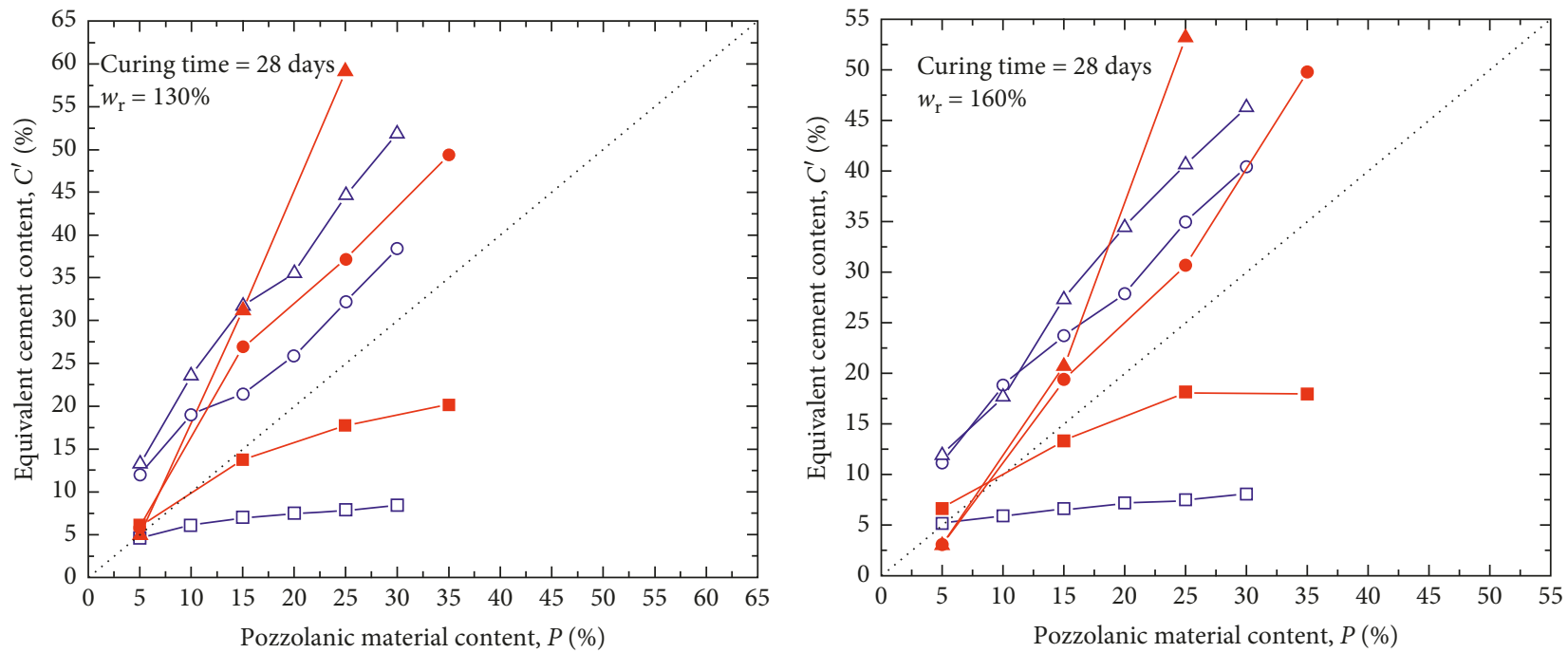

$$
\begin{array}{ll}
\text { Fly ash (data from [28]) } & \text { Rice husk ash (this study) } \\
-\square-C=10 \% & -\square-C=10 \% \\
-\circ-C=20 \% & -\bullet-C=20 \% \\
-\Delta-C=30 \% & -\Delta-C=35 \%
\end{array}
$$

$$
\begin{array}{ll}
\text { Fly ash (data from [28]) } & \text { Rice husk ash (this study) } \\
-\square-C=10 \% & -\square-C=10 \% \\
-\circ-C=20 \% & -\bullet C=20 \% \\
-\triangle-C=30 \% & -\Delta-C=35 \%
\end{array}
$$

(a)

(b)

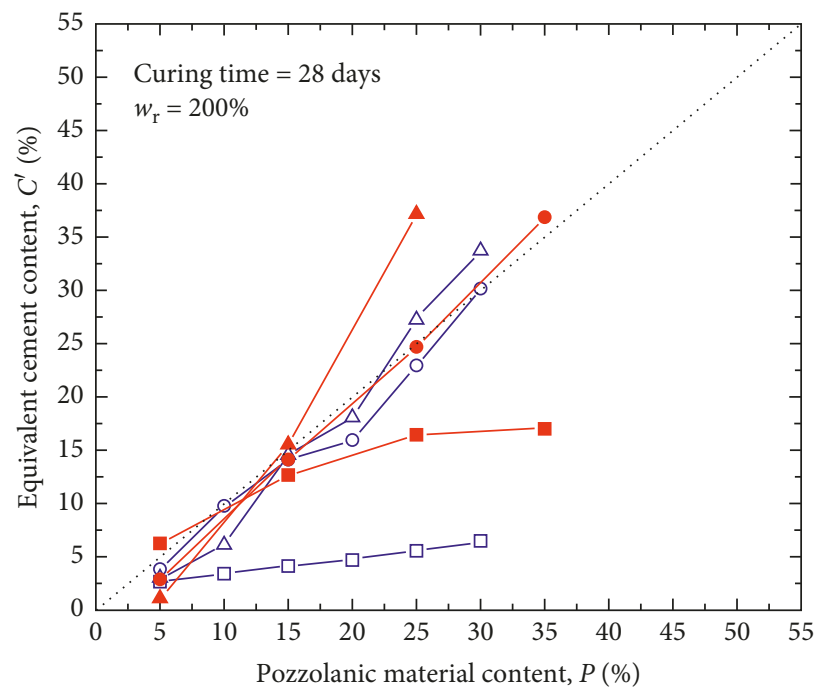

$$
\begin{array}{ll}
\text { Fly ash (data from [28]) } & \text { Rice husk ash (this study) } \\
-\square-C=10 \% & -\square-C=10 \% \\
-\circ-C=20 \% & -\bullet C=20 \% \\
-\triangle-C=30 \% & -\Delta-C=35 \%
\end{array}
$$

(c)

Figure 9: Relationships between calculated $C^{\prime}$ and actual pozzolanic content (RHA and fly ash) added in cement-treated soil at 28 days of curing time. $w_{\mathrm{r}}=130 \%$ (a); $160 \%$ (b); $200 \%$ (c).

\section{Conclusion}

Results from the experiments confirm that ground rice husk ash could be beneficially added into cement deep mixing to enhance the strength characteristics. The efficiency of rice husk ash depends on the proportion of the cement, rice husk ash, and water content in the mixtures as well as the curing time. The RHA enhances the strength of cement-admixed clay by larger than $100 \%$, depending on the addition rate and mixing components. For the curing period of 14 and 28 days and the range of water content in this study, the rice husk ash exhibits higher efficiency on Portland cement replacement when the cement and cementitious contents in the mixture are not less than 20 and 35\%, respectively. The RHA content in overall cementitious materials which enhances the strength of the mixture can be larger than 50\%. When compared with fly ash of similar grain size, the efficiency of rice husk ash is higher when the content to be added is greater than $15 \%$. 


\section{Data Availability}

The data used to support the findings of this study are available from the corresponding author upon request.

\section{Conflicts of Interest}

The authors declare that they have no conflicts of interest.

\section{Acknowledgments}

The authors are grateful for the support from the Department of Civil Engineering, King Mongkut's University of Technology Thonburi (CE-KMUTT-FTERO 5701). The authors also gratefully acknowledge Global Scales and Solution Company Limited, Nakornratchasima, Thailand, for providing the rice husk ash.

\section{References}

[1] J. James and P. K. Pandian, "Industrial wastes as auxiliary additives to cement/lime stabilization of soils," Advances in Civil Engineering, vol. 2016, Article ID 1267391, 17 pages, 2016.

[2] P. N. V. Jayanthi and D. N. Singh, "Utilization of sustainable materials for soil stabilization: state-of-the-art," Advances in Civil Engineering Materials, vol. 5, no. 1, pp. 46-79, 2016.

[3] G. Kuntikana and D. N. Singh, "Contemporary issues related to utilization of industrial byproducts," Advances in Civil Engineering Materials, vol. 6, no. 1, pp. 444-479, 2017.

[4] P. Chindaprasirt, P. Kanchanda, A. Sathonsaowaphak, and H. T. Cao, "Sulfate resistance of blended cements containing fly ash and rice husk ash," Construction and Building Materials, vol. 21, pp. 1356-1361, 2007.

[5] B. S. Thomas, "Green concrete partially comprised of rice husk ash as a supplementary cementitious material-a comprehensive review," Renewable and Sustainable Energy Reviews, vol. 82, pp. 3913-3923, 2018.

[6] V. Sata, C. Jaturapitakkul, and K. Kiattikomol, "Influence of pozzolan from various by-product materials on mechanical properties of high-strength concrete," Construction and Building Materials, vol. 21, no. 7, pp. 1589-1598, 2007.

[7] S. A. Zareei, F. Ameri, F. Dorostkar, and M. Ahmadi, "Rice husk ash as a partial replacement of cement in high strength concrete containing micro silica: evaluating durability and mechanical properties," Case Studies in Construction Materials, vol. 7, pp. 73-81, 2017.

[8] H. A. Mboya, C. K. King'ondu, K. N. Njau, and A. L. Mrema, "Measurement of pozzolanic activity index of scoria, pumice, and rice husk ash as potential supplementary cementitious materials for Portland cement," Advances in Civil Engineering, vol. 2017, Article ID 6952645, 13 pages, 2017.

[9] T. B. Edil, H. A. Acosta, and C. H. Benson, "Stabilizing soft fine-grained soils with fly ash," Journal of Materials in Civil Engineering, vol. 18, no. 2, pp. 283-294, 2006.

[10] S. Mor, C. K. Manchanda, S. K. Kansal, and K. Ravindra, "Nanosilica extraction from processed agricultural residue using green technology," Journal of Cleaner Production, vol. 143, pp. 1284-1290, 2017.

[11] M. Anwar, T. Miyagata, and M. Gaweesh, "Using rice husk ash as a cement replacement material in concrete," Waste Management Series, vol. 1, pp. 671-684, 2000.
[12] S. Rukzon and P. Chindaprasirt, "Use of ternary blend of Portland cement and two pozzolans to improve durability of high-strength concrete," KSCE Journal of Civil Engineering, vol. 18, no. 6, pp. 1745-1752, 2014.

[13] D. G. Montgomery and G. Chmeisse, "Soil stabilization using rice husk ash," Australian Road Research, vol. 21, no. 4, pp. 27-46, 1991.

[14] E. A. Basha, R. Hashim, H. B. Mahmud, and A. S. Muntohar, "Stabilization of residual soil with rice husk ash and cement," Construction and Building Materials, vol. 19, no. 6, pp. 448453, 2005.

[15] N. Yoobanpot and P. Jamsawang, "Effect of cement replacement by rice husk ash on soft soil stabilization," Kasetsart Journal-Natural Science, vol. 48, no. 2, pp. 323-332, 2014.

[16] K. Uddin, A. S. Balasubramaniam, and D. T. Bergado, "Engineering behavior of cement-treated Bangkok soft clay," Geotechnical Engineering, vol. 28, no. 1, pp. 89-119, 1997.

[17] P. Jamsawang, P. Voottipruex, P. Jongpradist, and D. T. Bergado, "Parameters affecting the lateral movements of compound deep cement mixing wall by numerical simulations and parametric analyses," Acta Geotechnica, vol. 10, no. 6, pp. 797-812, 2015.

[18] P. Jamsawang, P. Boathong, W. Mairaing, and P. Jongpradist, "Undrained creep failure of a drainage canal slope stabilized with deep cement mixing columns," Landslides, vol. 13, no. 5, pp. 939-955, 2015.

[19] A. Porbaha, "State of the art in deep mixing technology. Part II: applications," Proceeding of the Institution of Civil Engineers Ground Improvement, vol. 2, pp. 81-92, 1998.

[20] P. Jamsawang, N. Yoobanpot, N. Thanasisathit, P. Voottipruex, and P. Jongpradist, "Three-dimensional numerical analysis of a DCM column-supported highway embankment," Computers and Geotechnics, vol. 72, pp. 42-56, 2016.

[21] P. Jamsawang, S. Jamnam, P. Jongpradist, P. Tanseng, and S. Horpibulsuk, "Numerical analysis of lateral movements and strut forces in deep cement mixing walls with top-down construction in soft clay," Computers and Geotechnics, vol. 88, pp. 174-181, 2017.

[22] S. Waichita, P. Jongpradist, and C. Submaneewong, "Application of ground spring model in excavation supported by deep cement mixing," International Journal of Geomate, vol. 12, no. 31, pp. 30-36, 2017.

[23] P. Jongpradist, S. Youwai, and C. Jaturapitakkul, "Effective void ratio for assessing the mechanical properties of cementclay admixtures at high water content," Journal of Geotechnical Geoenvironment Engineering, vol. 137, no. 6, pp. 621-627, 2011.

[24] A. Wonglert and P. Jongpradist, "Impact of reinforced core on performance and failure behavior of stiffened deep cement mixing piles," Computers and Geotechnics, vol. 69, pp. 93-104, 2015.

[25] A. Wonglert, P. Jongpradist, P. Jamsawang, and S. Larsson, "Bearing capacity and failure behaviors of floating stiffened deep cement mixing columns under axial load," Soils and Foundations, vol. 58, no. 2, pp. 446-461, 2018.

[26] C. Phutthananon, P. Jongpradist, P. Yensri, and P. Jamsawang, "Dependence of ultimate bearing capacity and failure behavior of T-shaped deep cement mixing piles on enlarged cap shape and pile strength," Computers and Geotechnics, vol. 95, pp. 27-41, 2018.

[27] A. Farouk and M. M. Shahien, "Ground improvement using soil-cement columns: experimental investigation," Alexandria Engineering Journal, vol. 52, no. 4, pp. 733-740, 2013. 
[28] P. Jongpradist, N. Jumlongrach, S. Youwai, and S. Chucheepsakul, "Influence of fly ash on unconfined compressive strength of cement admixed clay at high water content," Journal of Materials in Civil Engineering, vol. 22, no. 1, pp. 49-58, 2010.

[29] G. Filz, T. Adams, M. Navin, and A. Templeton, "Design of deep mixing for support of levees and floodwalls," in Proceedings of the Geotechnical Special Publication (228 GSP), pp. 89-133, Reston, VA, USA, 2012.

[30] ASTM, "Standard specification for coal fly ash and raw or calcined natural pozzolan for use mineral admixture in Portland cement concrete," ASTM C, vol. 618, pp. 310-313, 2001.

[31] P. K. Mehta, "The chemistry and technology of cements made from rice husk ash," in Proceedings of the UNIDO/ESCAP/ RCTT Workshop on Production of Cement-like Materials from Agro-wastes, pp. 113-122, Peshawar, Pakistan, 1979.

[32] D. D. Bui, J. Hu, and P. Stroeven, "Particle size effect on the strength of rice husk ash blended gap-graded Portland cement concrete," Cement and Concrete Composites, vol. 27, no. 3, pp. 357-366, 2005.

[33] G. A. Lorenzo and D. T. Bergado, "Fundamental parameters of cement-admixed clay-new approach," Journal of Geotechnical and Geoenvironmental Engineering, vol. 130, no. 10, pp. 1042-1050, 2004.

[34] P. Jongpradist, S. Youwai, P. Manorat, W. Kongkitkul, and S. Chucheepsakul, "Influence of curing stress on onedimensional yielding of cement-admixed bangkok clay at high water content," Soils and Foundations, vol. 51, no. 2, pp. 351-357, 2011.

[35] ASTM, "Standard test method for unconfined compressive strength of cohesive soil," ASTM D, vol. 2166, pp. 1-6, 2002.

[36] S. H. Chew, A. H. M. Kamruzzaman, and F. H. Lee, "Physicochemical and engineering behavior of cement treated clays," Journal of Geotechnical and Geoenvironmental Engineering, vol. 130, no. 7, pp. 696-706, 2004.

[37] N. Miura, S. Horpibulsuk, and T. S. Nagaraj, "Engineering behavior of cement stabilized clay at high water content," Soils and Foundations, vol. 41, no. 5, pp. 33-45, 2001.

[38] C. Jaturapitakkul, K. Kiattikomol, V. Sata, and T. Leekeeratikul, "Use of ground coarse fly ash as a replacement of condensed silica fume in producing high-strength concrete," Cement and Concrete Research, vol. 34, no. 4, pp. 549-555, 2004.

[39] V. G. Papadakis and S. Tsimas, "Supplementary cementing materials in concrete. Part I: efficiency and design," Cement and Concrete Research, vol. 32, pp. 1525-1532, 2002.

[40] P. K. Mehta, "Properties of blended cements made from ricehusk ash," ACI Journal Proceedings, vol. 74, no. 9, pp. 440442, 1977. 


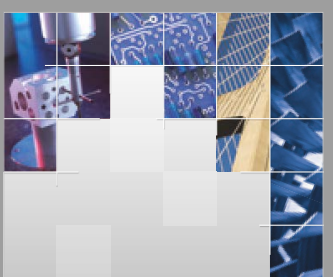

\section{Enfincering}
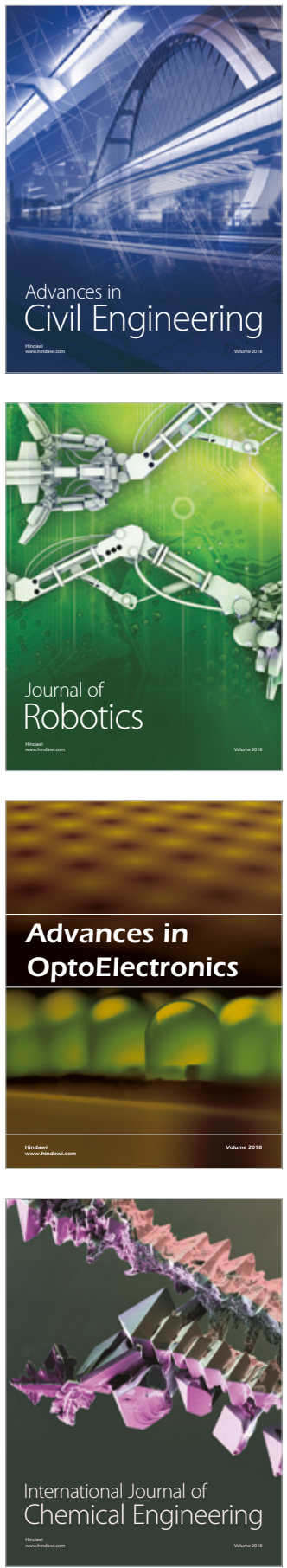

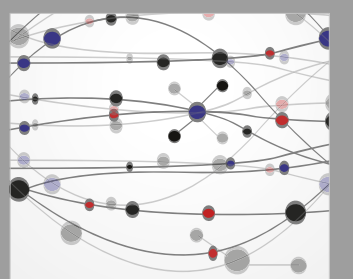

\section{Rotating \\ Machinery}

The Scientific World Journal

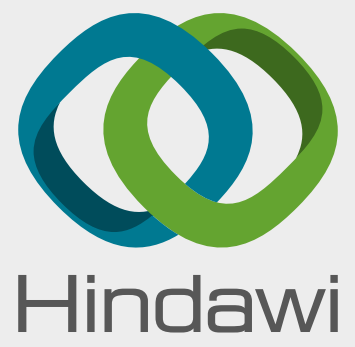

Submit your manuscripts at

www.hindawi.com
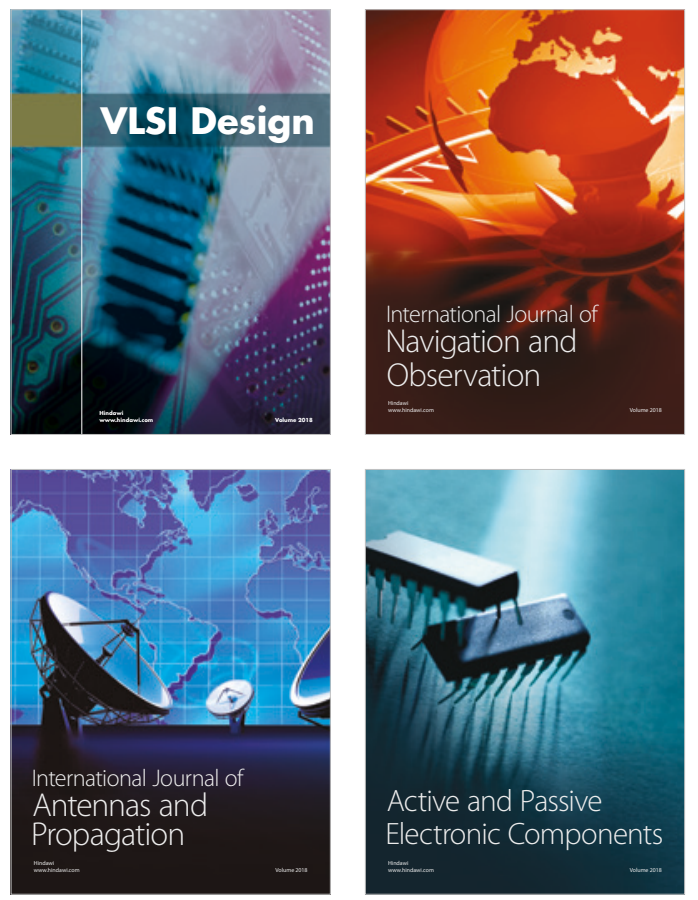
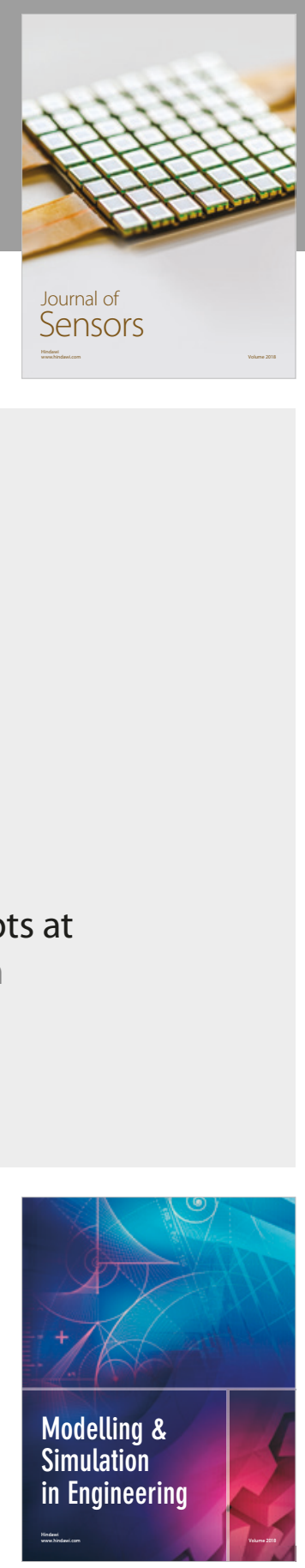

\section{Advances \\ Multimedia}
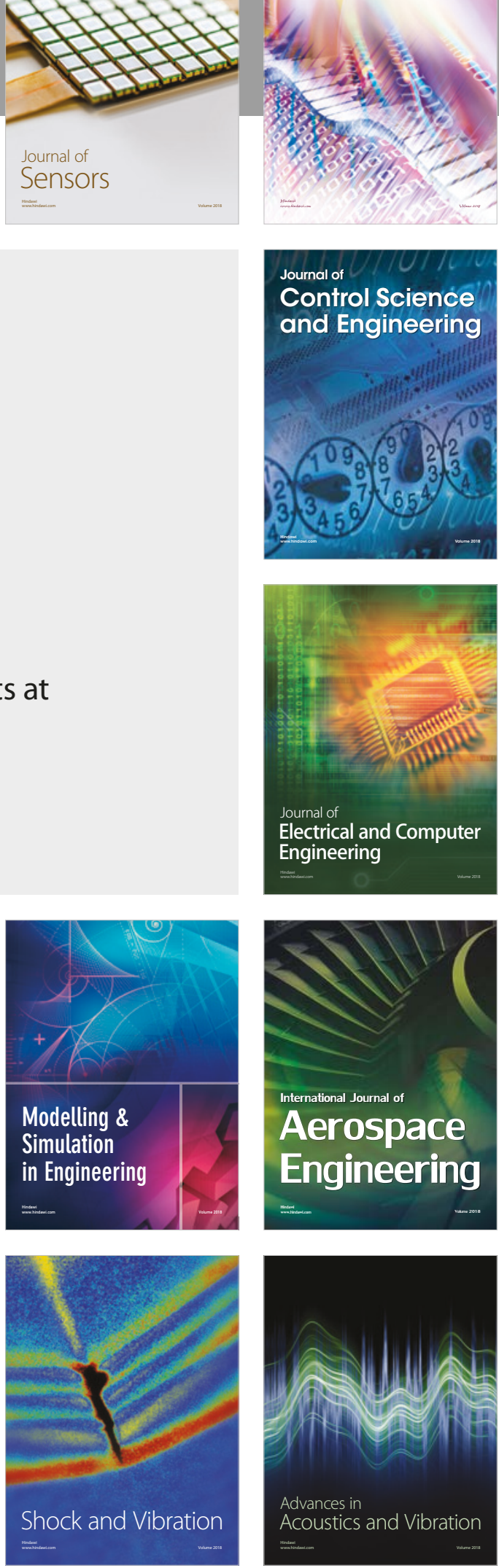